\author{
V.I. Golik 1,2 , \\ orcid.org/0000-0002-1181-8452, \\ Yu. V. Dmitrak ${ }^{2}$, \\ orcid.org/0000-0003-1278-4845, \\ V.S. Brigida ${ }^{3}$, \\ orcid.org/0000-0002-9421-5613
}

1 - Geophysical Institute of Vladikavkaz Scientific Centre of the Russian Academy of Sciences, Vladikavkaz, Russian Federation

2 - North Caucasian Institute of Mining and Metallurgy (State Technological University), Vladikavkaz, Russian Federation

3 - Federal Research Centre the Subtropical Scientific Centre of the Russian Academy of Sciences, Sochi, Russian Federation, e-mail: 1z011@inbox.ru

\title{
IMPACT OF DURATION OF MECHANOCHEMICAL ACTIVATION ON ENHANCEMENT OF ZINC LEACHING FROM POLYMETALLIC ORE TAILINGS
}

Purpose. Determination the impact of duration of mechanochemical activation on enhancement of zinc leaching from polymetallic ore tailings to ensure the sustainable mining.

Methodology. In experimental studies on the mechanical activation of geomaterial from the tails of Sadon polymetallic ores, the DESI-11 disintegrator was used. As a solution for leaching, a mixture with a different ratio of mass concentrations of hydrochloric and sulfuric acids was used. In addition, the ratio of solid and liquid fractions was varied from 1/4 to $1 / 10$ with process duration of 15 to 60 minutes. The results were processed by the standard LOESS method in combination with three-dimensional interpolation of an incomplete data sample.

Findings. Polynomial dependences have been established that make it possible to calculate the degree of zinc extraction from the tail, depending on the parameters of the process of the leached solution, the ratio of the solid and liquid phases in the pulp and the duration of agitation leaching.

Originality. For the first time, the mechanism of surface transformation, size and location of zones with maximum leaching efficiency with small changes in the duration of mechanical activation of the pulp was clarified.

Practical value. The revealed patterns can be used to optimize the parameters of agitation leaching by correlating the cost of energy consumption for increasing the duration of the process and unit costs for the lixiviants.

Keywords: greening ore mining, high-speed grinding, tailings, zinc leaching, disintegrator, mechanochemical effect

Introduction. One of the main problems the world mining industry is facing is the tailings disposal of the primary processing of metal ores. The technologies used in domestic companies for extracting metals from current and accumulated tailings have low efficiency due to the fact that they do not ensure the metal content reduction to the level of sanitary requirements. Their further utilization is considered unprofitable, because compensation for damage caused to the environment is partially carried out by the state in the form of compensation for loss of labor capacity, recreational costs, and others.

In turn, the resulting waste is a dangerous resource during storage, causing complex damage to all ecosystems of the natural environment without exception. The urgency of the problem is increased by the fact that at present the priority is given to technologies with the filling of industrial voids by hardening mixtures, for which tailings can serve as a substitute for binders [1]. In addition, the existing problems of an insufficient degree of environmentalization during heap (in stacks) and underground leaching of uranium necessitate the improvement of technological parameters for enrichment of georesources [2].

An effective measure to reduce technogenic risks is wastefree disposal of tailings, because other measures are not only ineffective, but also dangerous by creating conditions for the development of uncontrollable synergistic processes.

Prospects for waste-free utilization of enrichment tailings are associated with the use of the technology of mechanical activation of geomaterials, the founder of which is J. Hint. Later, his ideas were reflected in the concept of waste-free disposal of substandard tailings of the mining industry. This concept is based on the industrial use of the mechanical activation effect in combination with the optimal parameters of agitation leaching of useful components from polymetallic ore waste [3].

High grinding energy of disintegrators can cause rupture of the crystal structure, which reflects the current level of understanding of the "mechanochemical effect". This can lead to a

(C) Golik V. I., Dmitrak Yu. V., Brigida V. S., 2020 higher dissolution of copper [4]. A sharp decrease in the size of particles causes an increase in the specific surface area of mineral raw materials, which contributes to the improvement of the processes of extracting minerals and tailings. The creation of an induced defect structure and dislocations of the crystal lattice intensifies the development of new weakening planes. This increases the diffusion coefficient of the dissolved raw material, causing a large leaching kinetics of the metals. The intensification of structural defects and dislocations of the crystal lattice is accompanied by an increase in the reactivity, as well as the specific surface of the particles. This explains the attractiveness of a wider use of mechanical activation in the hydrometallurgical processing of ores and tailings.

Mechanochemical activation, as a process, is not just fine grinding, but the production of a physicochemical effect on materials. This causes changes in the physical and mechanical properties of polymetallic enrichment tailings. In contrast to magnetic separation [5], high-energy grinding of wastes leads to partial amorphization of the initial components at the atomic level with the possible formation of fine powders [6].

For example, two-hour treatment (or 1 hour with the simultaneous addition of sulfur) of laterite nickel ore containing $\mathrm{Fe}$ and $\mathrm{Mg}$ results in the formation of $\mathrm{FeMgS}$ with the release of $\mathrm{Ni}$ and $\mathrm{Co}$ [7]. These facts indicate that, in addition to accelerating the kinetics of leaching, the mechanochemical effect on mineral raw materials is accompanied by phase transformations of its constituent elements. At the same time, the results of the influence of the leaching duration and the addition of sulfur on the proportion of nickel yield from ore are interesting. From the analysis of Fig. 10 of [7], it follows that after activation of the ore and subsequent atmospheric leaching (with a concentration of $\mathrm{H}_{2} \mathrm{SO}_{4}=300 \mathrm{~g} / \mathrm{l}$ and a S/L ratio of 12.5 ) for $1 \mathrm{~h}$, the Ni yield was $62 \%$. With an increase in the duration of the process to $4 \mathrm{~h}$ (4 times), the proportion of $\mathrm{Ni}$ increases up to $77 \%$.

The addition of $\mathrm{S}$ in the first hour of enrichment led to the fact that the proportion of $\mathrm{Ni}=73 \%$, and with an increase in 
the duration of the process to $4 \mathrm{~h}-91 \%$. In this regard, it follows that a constant increase in the leaching time is accompanied by an increase slowdown in the proportion of metal from the enriched raw material. In this case, the addition of $\mathrm{S}$ can increase the efficiency of enrichment by $17 \%$ and does not change the general patterns of its course over time.

A decrease in the tailings size even at the boundary values of the operating modes of a mixing mill (in a stirred mill) can cause destruction of the crystal lattice, reducing the degree of crystallinity of $\mathrm{CuFeS}_{2}$ by $40 \%$ - a mechanochemical effect that increases the efficiency of Fe leaching by $35 \%$ (under the influence of $\mathrm{H}_{2} \mathrm{SO}_{4}$ ) [8]. The mechanochemical effect ensures the aggregation of the treated particles, increasing the rate of dissolution of clay-earth in cryolite, which excludes the formation of sediment [9]. When the powder steel charge is activated, the content of the fine fraction increases in comparison with the mixing technology [10]. Such systems of high-speed mixing of finely dispersed water in solutions with Surface Active Substance with coal mine methane contribute to the phase transition with the formation of gas hydrates (clathrates) [11].

One of the modern directions of mechanochemical impacts in fine grinding technologies is high-energy ball milling (HEM), one of the types of which is high-speed grinding (HSG) in impact-centrifugal mills - VSI mill (disintegrators). When processing in the mode of increasing energy impacts, it is possible to selectively destroy sulfide minerals and obtain concentrates with an increased content of non-ferrous metals during flotation. High-energy and high-speed impact on the mineral in the disintegrator increases the effect of destruction and promotes a more selective opening of intergrowths to the boundaries of mineral intergrowths and reduces the number of active fractions [12]. At the same time, the authors proposed to use stepwise grinding of geomaterial in the mode of increasing energy impact to obtain ore with fractions of $-0.071+0.02 \mathrm{~mm}$. The technological effect is achieved through a gradual change in the rotor speed in the disintegrator from 2400 to $7200 \mathrm{~min}^{-1}$. As a result of the multistage mechanical activation of the components and their subsequent flotation concentration, it is possible to bring up to half the volume of the tailings to the conditions of the ore mass with a copper content of about $0.58 \%$ [12].

It should also be noted that disintegrators-activators are already an element of technological lines, for example, in North Kazakhstan at the Shokpak deposit, it was mastered in mining at the end of the last century [5, 13].

It is known that the activation of nickel ores provides a significant increase in the efficiency of atmospheric leaching. Sample treatment for 120 min followed by treatment with $30 \%$ sulfuric acid at a ratio of liquid to solid phase $=1 / 2.5$ allows for yield of $80.6 \% \mathrm{Ni}$ and $84.5 \%$ Co [14]. In the absence of mechanochemical activation of the ore and the same conditions for the studied process, the same effect was obtained already at $480 \mathrm{~min}$. The use of the mechanochemical effect makes it possible to significantly improve the mechanical properties of the covering material for anodes (based on alumina). In [15], using the example of raw materials from the Achinsk and Nikolaevsk Alumina Combines, it was found that the use of M-3, R 400 or AGO-9 mills (continuous operation) to activate alumina increases the angle of repose from 30 to $47^{\circ}$, which significantly improves the quality of anode coating.

Demonstrative is the study [16] on the possibility of using natural quartz as a partial replacement of sand in cement slurry, due to the use of a disintegrator for its mechanochemical activation. It proved that the time factor is critical to ensure the increase in cement strength (up to $20 \%$ ) in uniaxial compression. In this case, the parameter of the rotor rotation speed during grinding was similar to ours and amounted to $3000 \mathrm{~min}^{-1}$. Despite this, the existing understanding of the kinetics and determination of the contribution for the mechanical action of disintegrators on the efficiency of metal recovery from the tailings, in the presence of several lixiviants in the leaching solution, are still very limited.

At the same time, there are few works aimed at investigating the parameters of multicomponent compositions of a leach solution in combination with HSG. For example, the use of multiple regression analysis of the results of the leaching of $\mathrm{Zn}$ and $\mathrm{Pb}$ from the tailings of the Sadon field made it possible to reveal that the concentration of $\mathrm{H}_{2} \mathrm{SO}_{4}$ exerts the greatest influence [13]. In this work, the authors evaluated, in addition to the composition of the solution, the role of the following factors: rotor frequency, leaching time, the number of tailings processing cycles, ratio of solid and liquid fractions in the pulp. The complexity of the approach and the multifactorial nature of the study does not allow for a sufficiently representative detailing of the contribution of each factor to the studied process. Based on the results presented by the authors of this work, the influence of the rotational speed of the rotors (changed from 50 to $200 \mathrm{~Hz}$ ) has a two-fold smaller effect than the leaching time for $\mathrm{Zn}$ and the same effect for $\mathrm{Pb}$. For leaching zinc, the similarity of the coefficients $X_{1}$ and $X_{3}$ of the equation given in Table 5 [13] it follows that the influence of the factors $\mathrm{S} / \mathrm{L}$ and $\mathrm{H}_{2} \mathrm{SO}_{4}$ is equivalent. Under the same conditions, during lead leaching, the ratio of the coefficients at $\mathrm{X}_{1}$ and $X_{3}$ is $1 / 3$, which significantly differs from the process of $Z n$ enrichment.

In our opinion, it would be worthwhile to conduct a multistage study with sequential control of the parameters of individual factors for the extraction degree of one metal type.

In addition to the fact that the mechanochemical activation of materials using disintegrators has many advantages, there is also a problem of high wear of the rotor pins. In our case, the DESI 11 disintegrator used for HSG study consists of two counter-rotating rotors with grinding pins. The effectiveness of its impact can be significantly lost due to the abrasion of the pins while, for example, the growth of the specific surface of the cement decreases to $50 \%$ [17]. This issue was not considered in our work, although it is important.

Purpose. The present study is aimed at determining the role of the minimum time of mechanochemical activation and variable technological factors on the efficiency of the agitation leaching of zinc from polymetallic wastes of the mining industry. The solution to this scientific and technical problem is necessary for solving the fundamental problem of the integrated development of georesources in the development of ore deposits and the sustainable development of geotechnologies.

In this regard, the purpose of the study is to determine the effect of the duration of mechanochemical activation on an increase in the degree of zinc leaching from the tailings

Methods. Experimental substantiation of the parameters of metal leaching was carried out using the enrichment tailings of ores of the Sadon lead-zinc plant (Mizur enrichment plant, Republic of North Ossetia - Alania). The mineralogical composition of the tailings is presented in Table 1.

In laboratory experiments for crushing and mechanical activation of geomaterial, a DESI-11 disintegrator (Tootmise OÜ, Estonia) was used, the productivity of which is from 10 to $20 \mathrm{~kg} / \mathrm{h}$, with a maximum rotational speed of $12000 \mathrm{~min}^{-1}$ and

Table 1

Composition of geomaterial for agitation leaching

\begin{tabular}{|l|c|c|c|c|c|c|c|c|c|c|c|c|}
\hline Element & $\mathrm{Pb}$ & $\mathrm{Zn}$ & $\mathrm{TiO}_{2}$ & $\mathrm{~S}$ & $\mathrm{CaO}$ & $\mathrm{SiO}_{2}$ & $\mathrm{Ag}$ & $\mathrm{Cu}$ & $\mathrm{Mn}$ & $\mathrm{K}_{2} \mathrm{O}$ & $\mathrm{Al}_{2} \mathrm{O}_{3}$ & $\mathrm{Fe}$ \\
\hline Content, $\%$ & 0.84 & 0.95 & 0.03 & 1.88 & 1.96 & 31.4 & 0.015 & 0.18 & 0.015 & 3.5 & 0.8 & 4.4 \\
\hline
\end{tabular}


a shock velocity up to $240 \mathrm{~m} / \mathrm{s}$. As lixiviants, a solution was prepared in advance from primary solutions of sulfuric acid (with a concentration of $2 ; 6 ; 10 \mathrm{~g} / \mathrm{l}$ ) and sodium chloride (with a concentration of $10 ; 90 ; 160 \mathrm{~g} / \mathrm{l}$ ). After mixing with different ratios of the reagents $\mathrm{H}_{2} \mathrm{SO}_{4}$ (for example: $2 \mathrm{~g}$ ) and $\mathrm{NaCl}$ (for example: $20 \mathrm{~g}$ ), 1 liter of solvent (prepared water) was poured in to form a final solution, which determines the liquid component of the future pulp.

The ratio of solid to liquid fraction (S/L) in the pulp was changed from $1 / 4$ to $1 / 10$. During the tests, $50 \mathrm{~g}$ samples of tailings, sifted through a $2.0 \mathrm{~mm}$ sieve, were mixed with a leaching solution (depending on the $\mathrm{S} / \mathrm{L}$ values) to obtain a pulp that was fed into a disintegrator (rotary speed $3000 \mathrm{~min}^{-1}$ ). To simulate the concentration parameters of the iron ores, Fourier series are currently being used, which is a very effective method, but too laborious to be applied in practice [18].

The experimental data were processed by the more reliable LOESS method [19] - local polynomial regression (based on the Stavitsky-Golay filter) for smoothing (revealing the approximating function) of the experimental data with further three-dimensional interpolation of the obtained values. The essence of this method is to use the scattered data after smoothing the nearest neighboring values as new nodal points. Scattered data are such points that do not have a common structure and are generally difficult to be analyzed by standard processing methods and statistical analysis. Data interpolation was performed according to the $C_{1}$ principle (once continuously differentiable) everywhere except for the nodal points, where there are discontinuities.

Results. Comparison between the results of mechanochemical activation at different duration of the process $(0.25 ; 0.625$ and 1 hour) was carried out in the presence of at least 6 options. To determine the enrichment efficiency, it was necessary to go from the concentration values of the reagents $\left(\mathrm{H}_{2} \mathrm{SO}_{4}\right.$ and $\left.\mathrm{NaCl}\right)$ to the proportions (by weight) of these reagents in the final pulp. This made it possible, subsequently, to have an idea of the relative economic efficiency of enrichment (comparing the unit costs for the purchase of reagents with the difference in energy costs for an increase in the leaching duration). Let us explain the implementation of the proposed approach using the example of experiment No. 1 (ratio $\mathrm{S} / \mathrm{L}==1 / 4, C_{\mathrm{H}_{2} \mathrm{SO}_{4}}=2 \mathrm{~g} / 1 ; \mathrm{CHCl}=$ $=20 \mathrm{~g} / \mathrm{l}$ ) for leaching duration $=15$ minutes. At the first stage, the total weight of 1 liter of the leach solution was determined

$$
\begin{array}{r}
M_{r}=988.5+C_{\mathrm{H}_{2} \mathrm{SO}_{4}}+C_{\mathrm{HCl}}, \quad \text { (1) form of a polynomial surface (coeff } \\
\mathrm{Zn}=\frac{\left(23.66-51.63 \mathrm{H}_{2} \mathrm{SO}_{4}+57.45 \mathrm{H}_{2} \mathrm{SO}_{4}^{2}+6.45 \mathrm{HCl}-\mathrm{HCl}^{2}+0.04 \mathrm{HCl}^{3}\right)}{\left(1-4.33 \mathrm{H}_{2} \mathrm{SO}_{4}+8.62 \mathrm{H}_{2} \mathrm{SO}_{4}^{2}-5.12 \mathrm{H}_{2} \mathrm{SO}_{4}^{3}+0.01 \mathrm{HCl}\right)},
\end{array}
$$

where $\mathrm{Zn}$ is the proportion of zinc extraction from the tailings, $\% ; \mathrm{H}_{2} \mathrm{SO}_{4}$ is mass fraction of sulfuric acid in the pulp, \%; $\mathrm{HCl}$ is mass fraction of sodium chloride in the pulp, $\%$.

The projection of function 3 at $t=0.25 \mathrm{~h}$ on the $\mathrm{H}_{2} \mathrm{SO}_{4}-$ $\mathrm{NaCl}$ axis is a nomogram (Fig. 2).

Fig. 2 shows that with a leaching duration of 0.25 hours, a decrease in the $\mathrm{NaCl}$ concentration from 12.5 to $1.5 \%$ (fraction in the pulp) at $0.1 \% \mathrm{H}_{2} \mathrm{SO}_{4}$ (fraction in the pulp) increases zinc extraction from 17 up to $43 \%$ (by 2.53 times); and at $0.9 \% \mathrm{H}_{2} \mathrm{SO}_{4}$, it increases zinc extraction from 37 to $83 \%$ (by 2.24 times). An increase in the concentration of $\mathrm{H}_{2} \mathrm{SO}_{4}$ from 0.1 to $0.9 \%$ at a value of $\mathrm{H}_{2} \mathrm{SO}_{4}=1.5 \%$ leads to an increase in the proportion of zinc extraction from 50 to $83 \%$ ( +33 or by where $C_{\mathrm{H}_{2} \mathrm{SO}_{4}}$ is the concentration of sulfuric acid in the solution, $\mathrm{g} / \mathrm{l} ; C_{\mathrm{HCl}}$ is the concentration of sodium salt of hydrochloric acid in the solution, $\mathrm{g} / \mathrm{l}$.

Further, the required mass of the liquid fraction was determined by multiplying the mass of the weighed portion of the tailings (constant value for all experiments $=50 \mathrm{~g}$ ) by the ratio L/S: $M_{g}=50 \cdot\left(\frac{S}{L}\right)=50 \cdot 4=200 \mathrm{~g}$. Then the mass of the pulp was determined by simple addition: $M_{p}=M_{g}+50=250 \mathrm{~g}$.

After that, the proportion of the reagent mass (for example, $\mathrm{H}_{2} \mathrm{SO}_{4}$ ) in the final mass of the concentrating pulp was determined by the following formula

$$
\omega_{\mathrm{H}_{2} \mathrm{SO}_{4}}=\left(\frac{\left(C_{\mathrm{H}_{2} \mathrm{SO}_{4}} / M_{r}\right) \cdot M_{g}}{M_{p}}\right) \cdot 100,
$$

where $C_{\mathrm{H}_{2} \mathrm{SO}_{4}}$ is the concentration of sulfuric acid (set at the beginning of the experiment), $\mathrm{g} / \mathrm{l} ; M_{r}$ is the mass of the primary solution, $\mathrm{g}$; $M_{g}$ is the required mass of the primary solution proceeding from the proportion of the liquid fraction, $\mathrm{g}$; $M_{p}$ is the mass of the final pulp, $\mathrm{g}$.

The proportion of the reagent mass of the hydrogen chloride in the final pulp was determined in a similar way. To increase the representativeness of the results obtained, the same parameters were selected for the first and third series of experiments (with $\min -15 \min$ and $\max -60$ min duration of the process) in accordance with Table 2 and Fig. 1.

During the mathematical processing of the obtained results, it became obvious that the minimum number of points does not allow drawing the "response surface" of the studied process with a sufficient degree of quality. In this regard, a strict interpolation procedure was applied to the available incomplete data sample - the triangulation procedure of prof. R.J.Renka. Strict interpolation procedures are algorithms that allow generating surface lines exactly passing through the available points, without smoothing the data.

By the three-dimensional interpolation method of the data of the first series of experiments, the analytical dependence of the degree of zinc extraction from the tailings on the parameters of the leached solution has been established, which has the form of a polynomial surface (coefficient $R^{2}=0.975$ )

$$
\mathrm{Zn}=\frac{\left(44.43+131.73 \mathrm{H}_{2} \mathrm{SO}_{4}-185.16 \mathrm{H}_{2} \mathrm{SO}_{4}^{2}+72.77 \mathrm{H}_{2} \mathrm{SO}_{4}^{3}-9.01 \mathrm{HCl}+0.39 \mathrm{HCl}^{2}\right)}{\left(1-0.14 \mathrm{H}_{2} \mathrm{SO}_{4}-0.04 \mathrm{HCl}\right)}
$$

The designations are the same as in Fig. 1

Fig. 4 shows that for $t=0.625 \mathrm{~h}$, a decrease in the concentration of $\mathrm{NaCl}$ from 12.5 to $1.5 \%$ at $0.1 \% \mathrm{H}_{2} \mathrm{SO}_{4}$ (fraction in the pulp) increases the extraction of zinc from 10 to $50 \%$ (by
$66 \%)$ with the formation of a local maximum $(\mathrm{Zn}=63 \%$, see zone "A" in Fig. 2) in the range from 0.3 to $0.4 \%$; and at a value of $\mathrm{H}_{2} \mathrm{SO}_{4}=12.5 \%$, stability is observed in the proportion of zinc extraction in $17 \%$ (from 0.1 to $0.7 \%$ of $\mathrm{NaCl}$ concentration), which is replaced by a sharp increase (37\% by 2.17 times)

The parameters of the second series of experiments at $t=$ $=0.625 \mathrm{~h}$ are presented in Table 3 and Fig. 3 . The surface projection of the studied process onto the $\mathrm{H}_{2} \mathrm{SO}_{4}-\mathrm{NaCl}$ axis can be represented by a nomogram (Fig. 4).

As a result of processing the results of the second series of experiments, an analytical dependence, that has the form of a polynomial surface $\left(R^{2}=0.988\right)$ was found 23 to $63 \%$ (by 2.73 times). An increase in the concentration of $\mathrm{H}_{2} \mathrm{SO}_{4}$ from 0.1 to $0.8 \%$ with a value of $\mathrm{H}_{2} \mathrm{SO}_{4}=1.5 \%$ increases the extraction of zinc from 50 to $63 \%$ (by $66 \%$ ) in the 
Table 2

Parameters of $\mathrm{Zn}$ leaching experiment version (at $t=0.25$ and $1 \mathrm{~h})$

\begin{tabular}{|c|c|c|c|c|c|c|}
\hline$\dot{z}$ & $\frac{1}{n}$ & 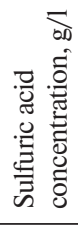 & 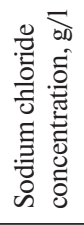 & 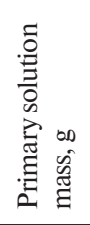 & 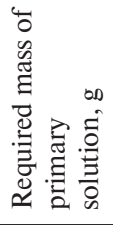 & 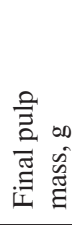 \\
\hline 1 & 2 & 3 & 4 & 5 & 6 & 7 \\
\hline 1 & $1 / 4$ & 2 & 20 & 1020.5 & 200 & 250 \\
\hline 2 & $1 / 10$ & 2 & 20 & 1020.5 & 500 & 550 \\
\hline 3 & $1 / 4$ & 2 & 160 & 1160.5 & 200 & 250 \\
\hline 4 & $1 / 10$ & 2 & 160 & 1160.5 & 500 & 550 \\
\hline 5 & $1 / 4$ & 10 & 20 & 1028.5 & 200 & 250 \\
\hline 6 & $1 / 10$ & 10 & 20 & 1028.5 & 500 & 550 \\
\hline 7 & $1 / 4$ & 10 & 160 & 1168.5 & 200 & 250 \\
\hline 8 & $1 / 10$ & 10 & 160 & 1168.5 & 500 & 550 \\
\hline 9 & $1 / 7$ & 6 & 90 & 1094.5 & 350 & 400 \\
\hline
\end{tabular}
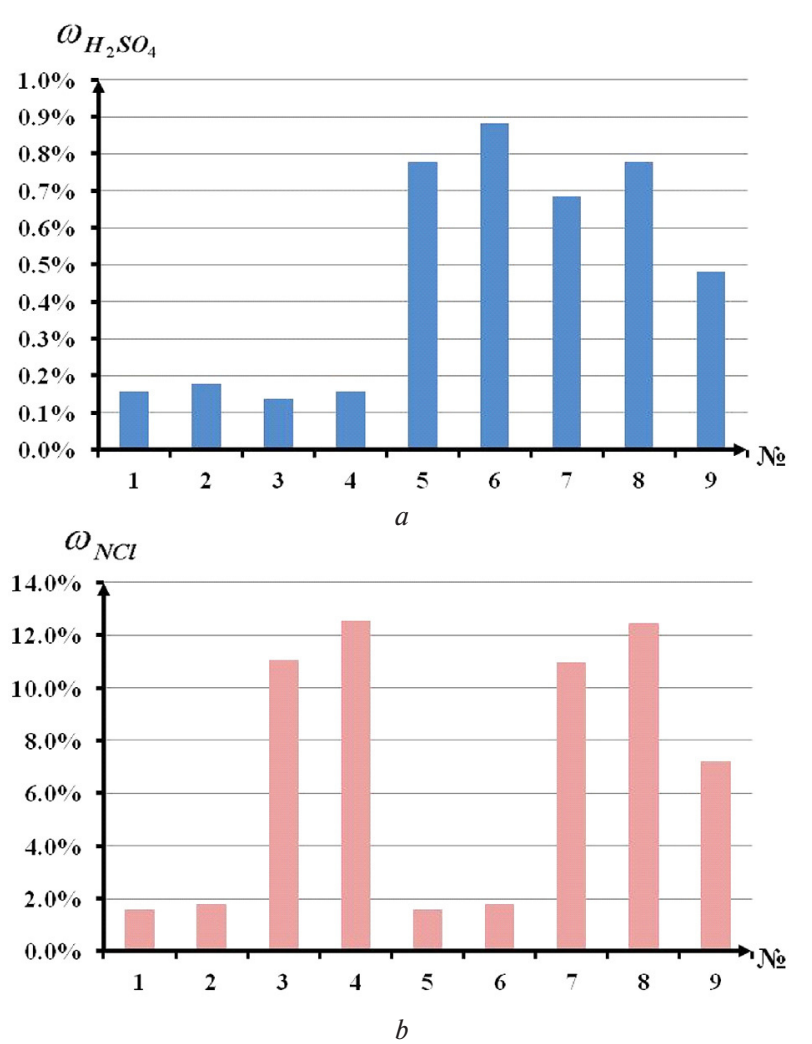

Fig. 1. Parameters of the final pulp in the first and third series of experiments with agitation leaching duration of 15 minutes and 60 minutes, respectively:

No - the number of the experiment; a - mass concentration of sulfuric acid in the pulp; $b$ - mass concentration of sodium chloride in the pulp

range from 0.1 to $0.3 \%$. An excess of $\mathrm{H}_{2} \mathrm{SO}_{4}$ concentration by more than $0.3 \%$ stabilizes the zinc yield; at a value of $\mathrm{H}_{2} \mathrm{SO}_{4}=$ $=12.5 \%$, zinc extraction increases from 10 to $30 \%$ (by 3 times).

As a result of the third series of experiments (parameters of which are given in Table 2 and Fig. 1), the analytical efficiency of zinc extraction from leaching parameters with a duration of $1 \mathrm{~h}$ was found, which has the following form (coefficient of approximation reliability $R^{2}=0.97$ )

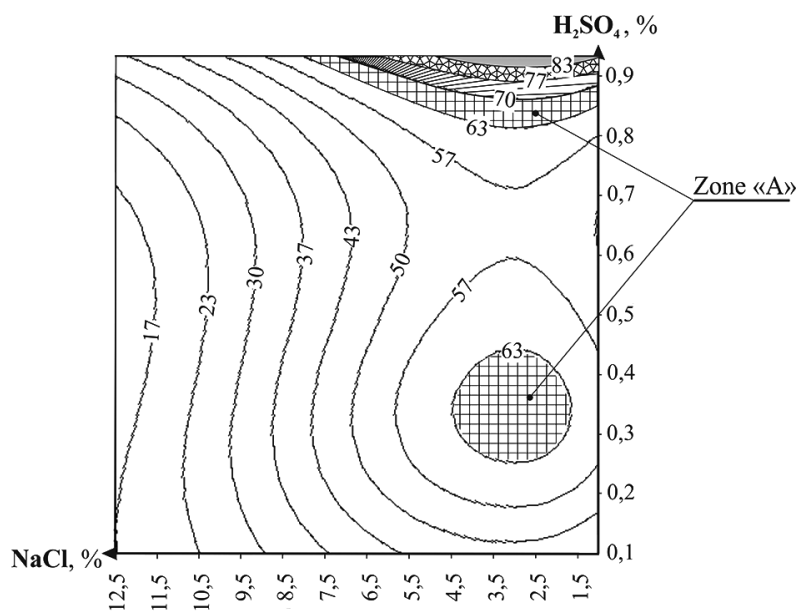

Fig. 2. Distribution of zinc yield depending on the concentration of sulfuric and hydrochloric acids

Table 3

Parameters of variants of $\mathrm{Zn}$ leaching experiments (at $t=0.625 \mathrm{~h}$ )

\begin{tabular}{|c|c|c|c|c|c|c|}
\hline$\dot{z}$ & $\frac{\vec{n}}{\omega}$ & 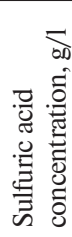 & 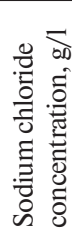 & 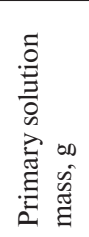 & 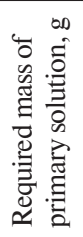 & 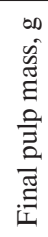 \\
\hline 1 & 2 & 3 & 4 & 5 & 6 & 7 \\
\hline 1 & $1 / 7$ & 2 & 90 & 1090.5 & 350 & 400 \\
\hline 2 & $1 / 7$ & 10 & 90 & 1098.5 & 350 & 400 \\
\hline 3 & $1 / 7$ & 6 & 20 & 1024.5 & 350 & 400 \\
\hline 4 & $1 / 7$ & 6 & 160 & 1164.5 & 350 & 400 \\
\hline 5 & $1 / 4$ & 6 & 90 & 1094.5 & 200 & 250 \\
\hline 6 & $1 / 10$ & 6 & 90 & 1094.5 & 500 & 550 \\
\hline
\end{tabular}

$$
\begin{gathered}
\mathrm{Zn}=21.20+351.76 \mathrm{H}_{2} \mathrm{SO}_{4}-7.76 \mathrm{HCl}-393.85 \mathrm{H}_{2} \mathrm{SO}_{4}^{2}+\ldots \\
+0.58 \mathrm{HCl}^{2}-17.64 \mathrm{H}_{2} \mathrm{SO}_{4} \cdot \mathrm{HCl}+55.20 \mathrm{H}_{2} \mathrm{SO}_{4}^{3}-\ldots \\
-0.15 \mathrm{H}_{2} \mathrm{SO}_{4} \cdot \mathrm{HCl}^{2}+19.68 \mathrm{H}_{2} \mathrm{SO}_{4}^{2} \cdot \mathrm{HCl} .
\end{gathered}
$$

Fig. 5 .

The projection of the polynomial function 5 is shown in

Fig. 5 shows that for a leaching time of 1 hour, a decrease in the concentration of $\mathrm{NaCl}$ from 12.5 to $1.5 \%$ at $0.1 \%$ $\mathrm{H}_{2} \mathrm{SO}_{4}$ (fraction in the pulp) increases the extraction of zinc from 10 to $50 \%$ (by 5 times); and at $0.9 \% \mathrm{H}_{2} \mathrm{SO}_{4}$ it increases the extraction of zinc from 10 to $57 \%$ (by 5.7 times). In addition, an increase in the concentration of $\mathrm{H}_{2} \mathrm{SO}_{4}$ from 0.1 to $0.9 \%$ at a value of $\mathrm{H}_{2} \mathrm{SO}_{4}=1.5 \%$ increases from 57 to $83 \%$ (by $45 \%$ ) zinc extraction with the formation of a local maximum in the range from 0.4 to $0.6 \%=\mathrm{H}_{2} \mathrm{SO}_{4}$; and with a value of $\mathrm{H}_{2} \mathrm{SO}_{4}=12.5 \%$ - to an increase from 10 to $26 \%$ (by 2.6 times), zinc extraction, with the formation of a local maximum in the range from 0.3 to $0.75 \%$ in $\mathrm{H}_{2} \mathrm{SO}_{4}$.

Based on the obtained results of the work, it follows that even a slight change in the time (up to $45 \mathrm{~min}$ ) of tailings activation when using a disintegrator significantly alters the efficiency of agitation leaching. Due to the large number of influencing parameters, for the full disclosure of the mechanism of the studied process, it is necessary to carry out clarifying experiments (for example, in the area of influence of the rotor speed changes). 

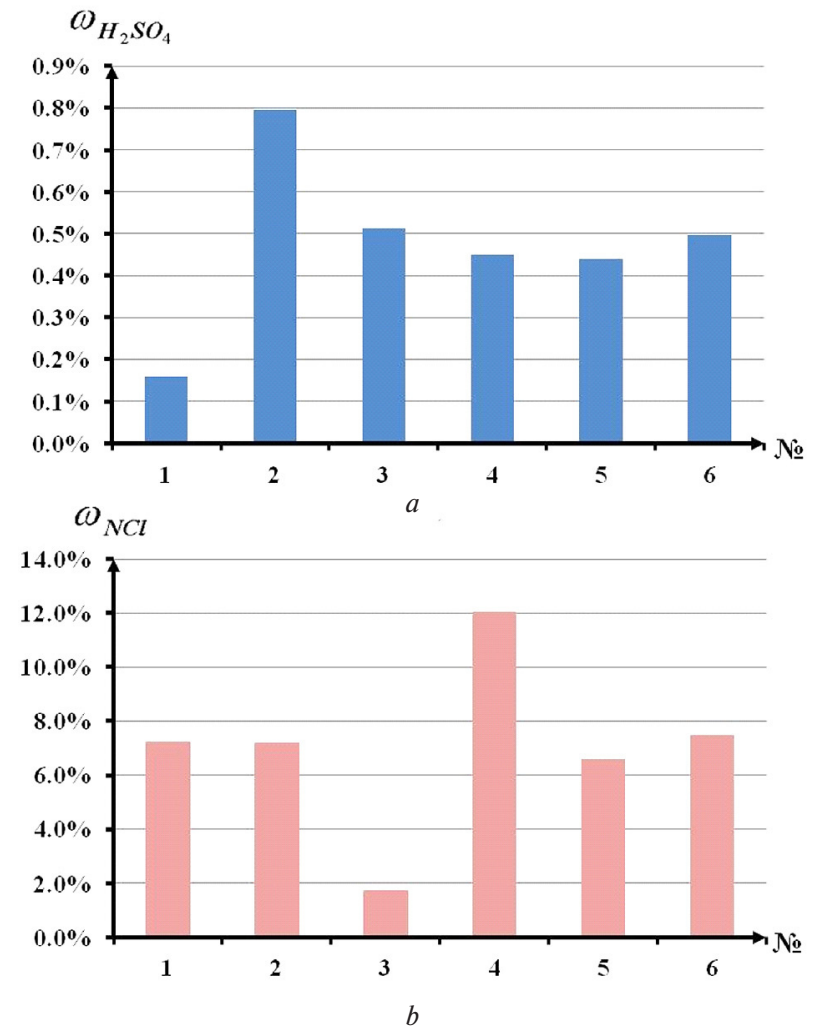

Fig. 3. Parameters of the final pulp in the first and third series of experiments at $t=38 \mathrm{~min}$

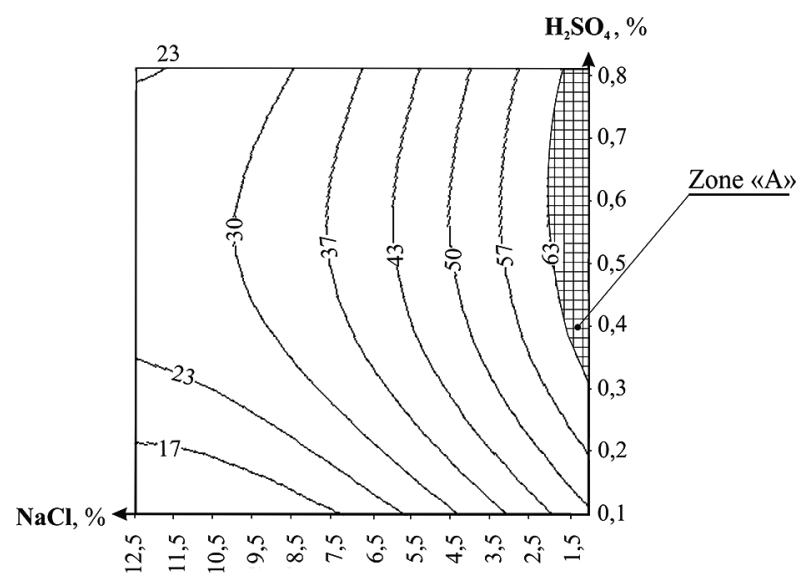

Fig. 4. Extraction of zinc at $t=0.625 \mathrm{~h}$

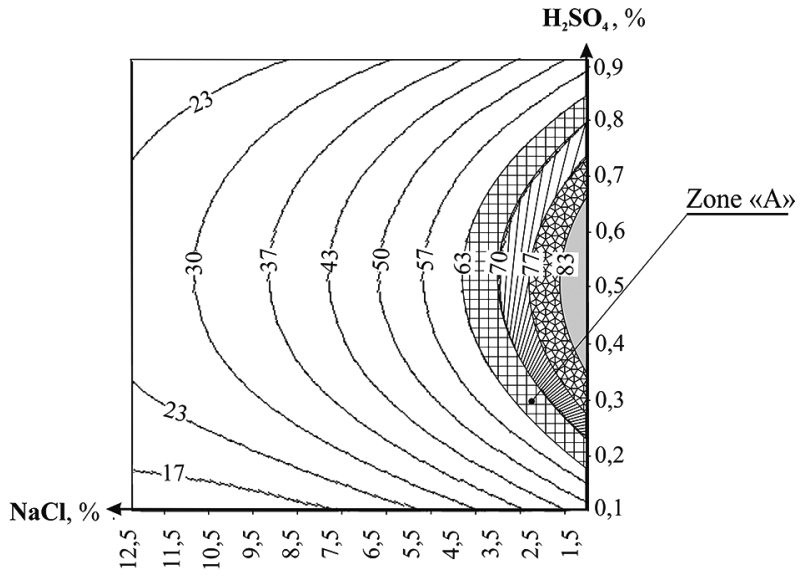

Fig. 5. Zinc recovery with leaching duration $=1 \mathrm{~h}$
The proportion of zinc yield during mechanical activation of leached tailings increases unevenly (with the formation of local maxima). This happens according to the polynomial law with an increase in the concentration (by mass) of sulfuric acid and a decrease in the proportion of hydrochloric acid in the pulp, if the duration of the process does not exceed $0.25 \mathrm{~h}$.

An increase in the using time of the disintegrator to $0.6 \mathrm{~h}$ significantly changes the surface of the efficiency of zinc leaching, increasing more evenly with an increase in sulfuric acid and a decrease in hydrochloric acid in the pulp, the maximum of which is localized in the $\mathrm{H}_{2} \mathrm{SO}_{4}$ range from 0.3 to $0.8 \%$ and $\mathrm{NaCl}$ not exceeding $2.5 \%$.

In this case, the migration and change in the size of the productive area in the second series of experiments (Zone "A" in Fig. 2), in comparison with the first one, causes a deterioration in the leaching efficiency. In our opinion, this is due to the differences in the planning variants of the second series of experiments from the first and the third (where the parameters were completely identical). This fact confirmed the correctness of the general concept of the need to plan series with the same $\mathrm{S} / \mathrm{L}$ ratios, as well as $\omega_{\mathrm{H}_{2} \mathrm{SO}}$ and $\omega_{\mathrm{HCl}}$. Similar phenomena were observed in [16] on determining the effect of the grinding time under the action of a disintegrator on the reactivity of sand in a cement mortar. The addition of quartz sand to concrete, immediately after mechanochemical activation in a DSL-115 disintegrator with a rotor speed of $3000 \mathrm{~min}^{-1}$ and an impact speed of $150 \mathrm{~m} / \mathrm{s}$, provided an increase (by $14 \%$ ) in its compressive strength. The change in the composition of the mixture for the preparation of the solution led to the fact that the gain in both instantaneous (after 7 days) and long-term (28 days) strength reached significant values - from 4 to $11 \%$.

If the processes of mechanochemical activation of a material and metal leaching are separated in time, similar patterns can be traced. The highest yield of useful components is observed when the activation time coincides with the leaching duration. For example, in [14] the duration of mechanical action was 1, 2 and 3 hours, while the same tendencies were observed in the change in the efficiency of extraction of nickel, iron and cobalt from ore depending on the leaching time. An increase in the processing time of samples in mills from 1 to 3 hours did not significantly increase the yield of any of the metals. At the same time, the absence of mechanical action significantly reduced the efficiency of the process, with an increase in the duration of atmospheric leaching to $240 \mathrm{~min}$.

The greatest effect was exerted by the time factor $(S / L=$ $=1 / 9$ by weight when exposed to $20 \% \mathrm{H}_{2} \mathrm{SO}_{4}$ ): an increase in the leaching duration from 60 to 120 min leads to an increase in the proportion of Ni yield from 88 to $98 \%$ and then is not changing; Co yield increases from 96 to $98 \%$; Fe yield - from 82 to $90 \%$ [14]. In this regard, it should be emphasized that most of the increment in the positive effect is achieved in the first 60 minutes of the leaching process with pre-activated (at least 1 hour) ore samples.

As in our case (similar to the different $S / L$ parameters in the second series of experiments), the ratio of the mixture ingredients leads to unevenness in the activation efficiency of inert fillers.

Similar results were obtained when grinding chalcopyrite [8] in a pin type vertical stirred mill, when, with the same mechanochemical effect (the assessment was carried out by the degree of crystallinity - DOC), the kinetics of $\mathrm{Cu}$ leaching under the action of $\mathrm{H}_{2} \mathrm{SO}_{4}$ was by $30 \%$ higher than under the action of HCL (increase in dissolution rate $=35$ versus $25 \%$ ). Based on the above, it is obvious that the leaching efficiency is significantly influenced by the concentration ratio and reactivity of the lixiviants types, which reduces the reliability of revealing the degree of positive effect of mechanochemical activation on the $\mathrm{Zn}$ yield.

One of the most important results of our study is that the achievement of a maximum mechanical activation time of up to $1 \mathrm{~h}$ compared to $t=0.25 \mathrm{~h}$ transforms the surface of zinc 
extraction. This process is accompanied by migration and expansion of the size of the high-performance zone (Zone "A") towards a lower concentration of sulfuric acid and an increase in the metal yield from 63 to $83 \%$.

These results are confirmed by experiments on the disposal of metallurgical waste. In work [20], the enrichment of bauxitic clay (to obtain lithium) was carried out using sulfuric acid while changing its composition. To obtain $\mathrm{Li}, \mathrm{Al}, \mathrm{Fe}$, and $\mathrm{Mg}$, clay samples were calcined at a temperature of $600{ }^{\circ} \mathrm{C}$ and then exposed to sulfuric acid with a concentration of $15 \mathrm{wt} / \mathrm{vol} \%$, the ratio of liquid to solid fraction was $5 / 1(\mathrm{ml} / \mathrm{g})$. As a result, it was found that the duration of the reaction significantly increases the leaching efficiency only within the first hour. Further, the yield curves of useful components were cooled, and the growth of the process efficiency slowed down to $<15 \%$ with an increase in $t$ from 60 to $300 \mathrm{~min}$. The highest metal yield is observed in $\mathrm{Li}$ and is about $74 \%$, which, with an increase in the leaching time to $300 \mathrm{~min},=84 \%$. The lowest efficiency of the process is observed for Al. With an increase in the duration of enrichment from 60 to $300 \mathrm{~min}$, the metal yield changed from 24 to $28 \%$, respectively. In this regard, general trends indicate an extremely high (up to $85 \%$ of the total yield of useful components) importance of the first hour of mechanochemical activation in the implementation of agitation leaching. In another similar study [7], the effect of the mechanism of mechanochemical processing of lateritic nickel ore in vibrating ball mill (ESM, Germany) on the recovery of $\mathrm{Ni}, \mathrm{Fe}$ and Co was studied. The laterite samples were processed in a mill for $1 \mathrm{~h}$ with the addition of $\mathrm{S}-20 \%$, the rotor speed was $960 \mathrm{~min}^{-1}$, at a concentration of $\mathrm{H}_{2} \mathrm{SO}_{4}=200,250,300,400 \mathrm{~g} / 1$ and a $\mathrm{S} / \mathrm{L}$ ratio of $1 / 2.5$. As a result of changing the leaching duration from 1 to 7 hours, $95 \%$ of the total increase in the yield of $\mathrm{Ni}, \mathrm{Fe}$ and $\mathrm{Co}$ was on the first hour of processing, which made it possible to achieve a high proportion of the yield of metals (at the level of 70-80\%). This indirectly confirms that a small increase in leaching efficiency from 0.25 to $1 \mathrm{~h}$ in our study, resulting in the level of $\mathrm{Zn}$ extraction $=83 \%$ can be considered quite representative. In addition, the results of the dynamics of the extraction yield during the leaching of $\mathrm{Cu}$ with sulfuric acid and the mechanochemical activation of ore in planetary ball milling and stirred ball milling for 100 hours are indicative [4]. Regardless of the type of mills and changes in the rotor speed of $110,247,349,382,428 \mathrm{~min}^{-1}$ in the initial period (up to 9 hours), the maximum kinetics of leaching is observed, after which, with each new hour, the positive effect from mechanical activation falls. This fact determines the need for subsequent studies on the dynamics of the decline in the productivity of $\mathrm{Zn}$ extraction with a longer duration of the studied process - up to $9 \mathrm{~h}$.

The obtained results broaden the understanding of the influence mechanism of the mechanochemical action duration, which determines the change in the activity of polymetallic tails at different ratios of the two types of lixiviants, on the degree of zinc extraction from them. For the practice of mining production, as a result of establishing new dependencies, it will allow solving the problems of optimizing the parameters of agitation leaching of waste based on a comparison of the energy consumption cost for an increase in the enrichment time and the specific cost of a solution for leaching with a change in mass concentrations of $\mathrm{H}_{2} \mathrm{SO}_{4}$ and $\mathrm{NaCl}$.

Conclusion. The main scientific results and conclusions that reveal the duration effect of the mechanical activation for polymetallic tailings (with the help of a disintegrator, sulfuric acid and sodium chloride) on the transformation mechanism of the efficiency for agitation leaching of $\mathrm{Zn}$ are as follows:

- it was found that with the duration of mechanochemical activation of tailings $=15 \mathrm{~min}$, an increase in the mass fraction of $\mathrm{H}_{2} \mathrm{SO}_{4}$ from 0.1 to $0.9 \%$ and a decrease in the fraction of $\mathrm{NaCl}$ from 12.5 to $1.5 \%$ in the pulp lead to a nonlinear increase in the degree of zinc extraction, according to the polynomial dependence by 2.5 and more times (for boundary values);

- it was found that according to the polynomial dependence an increase in the leaching time up to $38 \mathrm{~min}$, as well as an increase in the proportion of $\mathrm{H}_{2} \mathrm{SO}_{4}$ from 0.1 to $0.8 \%$ with a decrease in $\mathrm{NaCl}$ from 12.5 to $1.5 \%$ in the pulp, causes an increase in the zinc yield to a level of $63 \%$;

- it was determined that when the duration of agitation leaching $=60$ minutes is achieved, with other conditions of changes in the reagents in the pulp being equal, there occurs an increase in the polynomial dependence of the proportion of zinc yield up to $83 \%$;

- it was revealed that a slight change in the duration of mechanochemical activation causes surface transformation of the degree of zinc extraction depending on the composition of the leached solution. This process is accompanied by migration and a change in the size of the zone of maximum zinc yield in tailing. All these necessitate the development of new approaches to substantiating the optimum technological parameters for activating polymetallic ore wastes;

- the relationship mechanism between the duration of the studied process and the composition of the leached solution was clarified. It consists in modifying the surface shape of the $\mathrm{Zn}$ extraction efficiency (Zone "A") towards the minimum values of the $\mathrm{NaCl}$ fraction ( $\geq 3.5 \%$ by pulp mass) symmetrically relative to the concentration of $\mathrm{H}_{2} \mathrm{SO}_{4}$ (in the range from 0.45 to $0.55 \%$ ) and an increase in the metal yield from 63 to $83 \%$.

An experimental assessment of the role of variable technological factors in the process of mechanical activation during zinc leaching from ore dressing tailings of a particular deposit has confirmed the technological possibility of controlling the properties of minerals using a disintegrator. The established relationships between the concentrations of reagents and the efficiency of extracting metals from waste create the basis for directed management of tailing disposal processes with obtaining an ecological and economic effect from the use of reserves of technogenic deposits.

The technology of using disintegrators for the mechanical activation of mining waste is an unused reserve for increasing industrial zinc production.

The results obtained necessitate further research in the field of: confirmation of "deformation" to the worse side of the effective leaching surface of another type of metal (for example, $\mathrm{Pb}$ or $\mathrm{Cu}$ ) for $t=0.625 \mathrm{~h}$; revealing the influence mechanism of the $\mathrm{S} / \mathrm{L}$ ratios, as well as $\omega_{\mathrm{H}_{2} \mathrm{SO}_{4}} / \omega_{\mathrm{HCl}}$ on the effectiveness of mechanochemical activation of tails; establishing the role of the rotor speed in the extraction of several types of metals.

\section{References.}

1. Komashchenko, V.I., Vorobev, E. D., \& Razorenov, Y.I. (2017). Extraction of metals when recycling enrichment of ores. Bulletin of the Tomsk Polytechnic University, Geo Assets Engineering, 328(10), 18-24. http://earchive.tpu.ru/handle/11683/43364.

2. Rakishev, B.R., Bondarenko, V.I., Matayev, M.M., \& Kenzhetayev, Z.S. (2019). Influence of chemical reagent complex on intensification of uranium well extraction. Naukovyi Visnyk Natsionalnoho Hirnychoho Universytetu, (6), 25-30. https://doi.org/10.29202/nvngu/2019-6/4.

3. Golik, V., Komashchenko, V., \& Morkun, V. (2015). Feasibility of using the mill tailings for preparation of self-hardening mixtures. Metallurgical and Mining Industry, (3), 38-41.

4. Minagawa, M., Hisatomi, Sh., Kato, T., Granata, G., \& Tokoro, Ch. (2018). Enhancement of copper dissolution by mechanochemical activation of copper ores: Correlation between leaching experiments and DEM simulations. Advanced Powder Technology, 29(3), 471-478. https://doi.org/10.1016/i. apt.2017.11.031. 
5. Bouabdallah, S., Bounouala, M., Idres, A., \& Chaib, A. (2015). Iron removal process for high-purity silica production by leaching and magnetic separation technique. Naukovyi Visnyk Natsionalnoho Hirnychoho Universytetu, (5), 47-52.

6. Chen, G., Chen, J., \& Peng, J. (2015). Effect of mechanical activation on structural and microwave absorbing characteristics of high titanium slag. Powder Technology, 286, 218-222. https://doi.org/10.1016/j.powtec.2015.08.021.

7. Basturkcua, H., Achimovičováb, M., Kaňuchovád, M., \& Acarkana, N. (2018). Mechanochemical pre-treatment of lateritic nickel ore with sulfur followed by atmospheric leaching. Hydrometallurgy, 181, 43-52. https://doi.org/10.1016/i.hydromet.2018.08.016.

8. Palaniandy, S. (2015). Impact of mechanochemical effect on chalcopyrite leaching. International Journal of Mineral Processing, 136, 56-65. https://doi.org/10.1016/j.minpro.2014.10.005. 9. Yushkova, O.V., Isaeva, L.A., Polyakov, P.V., \& Avvakumov, E. G. (2018). The influence of mechanical activation on the dust index and the dissolution rate of alumina in the molten cryolite. Tsvetnye Metally, 8, 63-68. https://doi. org/10.17580/tsm.2018.08.08.

10. Sergeenko, S. N. (2019). Kinetics of dispersion-agglomeration processes during mechanical activation of the charge of $110 \mathrm{~g} 13$ powder steel. Chernye Metally, (7), 47-52.

11. Bondarenko, V., Kovalevska, I., Astafiev, D., \& Malova, O. (2018). Effect of mechanoactivated chemical additives on the process of gas hydrate formation. Eastern-European Journal of Enterprise Technologies, 1, 6(91), 17-26. https://doi. org/10.15587/1729-4061.2018.123885.

12. Yusupov, T.S., Kirillova, E.A., Shumskaya, L. G., Isupov, V.P., \& Lyakhov, N. Z. (2017). Improvement of flotation enrichment of copper-nickel ores based on the selective destruction of mineral aggregates in high-energy impact. Chemistry for Sustainable Development, 4, 422-428. https://doi. org/10.15372/CSD20170413.

13. Golik, V., Morkun, V., Morkun, N., \& Tron, V. (2019). Investigation of mechanochemical leaching of non-ferrous metals. Acta Mechanica et Automatica, 13(2), 113-123. https:// doi.org/10.2478/ama-2019-0016.

14. Basturkcua, H., Acarkan, N., \& Gock, E. (2017). The role of mechanical activation on atmospheric leaching of a lateritic nickel ore. International Journal of Mineral Processing, 163, 1-8. https://doi.org/10.1016/i.minpro.2017.04.001.

15. Yushkova, O. V., Yasinskiy, A. S., Polyakov, P. V., \& Yushkov, V. V. (2020). Use of mechanical activation to improve the performance of anode cover material. Tsvetnye Metally, 1(925), 54-59. https://doi.org/10.17580/tsm.2020.01.08.

16. Bumanisa, G., \& Bajarea, D. (2017). Compressive strength of cement mortar affected by sand microfiller obtained with collision milling in disintegrator. Procedia Engineering, 172, 149-156. https://doi.org/10.1016/j.proeng.2017.02.037.

17. Dvořák, K., Dolák, D., Paloušek, D., Čelko, L., \& Jech, D. (2018). The effect of the wear of rotor pins on grinding efficiency in a high-speed disintegrator. Medziagotyra, 24(1), 29-34. https://doi.org/10.5755/i01.ms.24.1.17737.

18. Morkun, V.S., Morkun, N.V., Tron, V.V., Hryshchenko, S. M., Suvorov, O.I., Paraniuk, D. I., \& Serdiuk, O.J. (2019). Reducing dimension of spatio-temporal models of nonlinear dynamic processes of iron ore raw materials enrichment. Bulletin of the Tomsk Polytechnic University. Geo Assets Engineering, 330(12), 151-167. https://doi.org/10.18799/24131 $\underline{830 / 2019 / 12 / 2416}$

19. Brigida, V.S., Golik, V. I., Dmitrak, Yu.V., \& Gabaraev, O.Z. (2019). Ensuring stability of undermining inclined drainage holes during intensive development of multiple gasbearing coal layers. Journal of Mining Institute, 239, 497-501. https://doi.org/10.31897/PMI.2019.5.497.

20. Gu, H., Guo, T., Wen, H., Luo, Ch., Cui, Y., Du, Sh., \& Wang, N. (2020). Leaching efficiency of sulfuric acid on selective lithium leachability from bauxitic claystone. Minerals Engineering, 145(106076).https://doi.org/10.1016/j.mineng.2019.106076.

\section{Вплив тривалості механохімічної активації на підвищення ступеня вилуговування цинку із хвостів поліметалевих руд}

\author{
В. І. Голик ${ }^{1,2}$, Ю.В. Дмитрак ${ }^{2}$, В.С. Бригіда ${ }^{3}$
}

1 - Геофізичний інститут - філія Федеральної державної бюджетної установи науки Федерального наукового центру «Владикавказький науковий центр Російської академії наук», м. Владикавказ, Російська Федерація

2 - Північно-Кавказький гірничо-металургійний інститут (державний технологічний університет), м. Владикавказ, Російська Федерація

3 - Федеральний дослідницький центр «Субтропічний науковий центр Російської академії наук», м. Сочі, Російська Федерація, e-mail: 1z011@inbox.ru

Мета. Визначення впливу тривалості механохімічної активації на підвищення ступеня вилуговування цинку із хвостів збагачення для забезпечення сталого розвитку геотехнологій.

Методика. В експериментальних дослідженнях з механоактивації геоматеріалу із хвостів поліметалічних руд Садону використовувався дезінтегратор DESI-11. В якості розчину для вилуговування використовували суміш $з$ різним співвідношенням масових концентрацій соляної й сірчаної кислот. Крім цього, співвідношення твердої та рідкої фракції змінювали від 1/4 до 1/10 при тривалості процесу від 15 до 60 хв. Отримані результати оброблялись стандартним методом LOESS у поєднанні 3 тривимірною інтерполяцією неповної вибірки даних

Результати. Встановлені поліноміальні залежності, що дозволяють розрахувати ступінь вилучення цинку із хвостів збагачення за параметрами процесу вилуговування розчину, співвідношенню твердої та рідкої фази в пульпі, а також тривалості агітаційного вилуговування.

Наукова новизна. Уперше уточнено механізм трансформації поверхні, розмірів і розташування зон із максимальною ефективністю вилуговування при малих змінах тривалості механоактивації пульпи.

Практична значимість. Виявлені закономірності можуть бути використані для оптимізації параметрів агітаційного вилуговування шляхом співвідношення вартості енерговитрат на збільшення тривалості процесу й питомих витрат на компоненти вилуговуючого розчину.

Ключові слова: екологізація видобутку руди, високошвидкісне подрібнення, хвости збагачення, вилуговування иинку, дезінтегратор, механохімічний ефект

\section{Влияние продолжительности механохимической активации на повышение степени выщелачивания цинка из хвостов полиметаллических руд}

\section{В. И. Голик ${ }^{1,2}$, Ю. В. Дмитрак ${ }^{2}$ В. С. Бригида}

1 - Геофизический институт - филиал Федерального государственного бюджетного учреждения науки Федерального научного центра «Владикавказский научный центр Российской академии наук», г. Владикавказ, Российская Федерация

2 - Северо-Кавказский горно-металлургический институт (государственный технологический университет), г. Владикавказ, Российская Федерация

3 - Федеральный исследовательский центр «Субтропический научный центр Российской академии наук», г. Сочи, Российская Федерация, e-mail: 1z011@inbox.ru 
Цель. Определение влияния продолжительности механохимической активации на повышение степени выщелачивания цинка из хвостов обогащения для обеспечения устойчивого развития геотехнологий.

Методика. В экспериментальных исследованиях по механоактивации геоматериала из хвостов полиметаллических руд Садона использовался дезинтегратор DESI11. В качестве раствора для выщелачивания использовали смесь с различным соотношением массовых концентраций соляной и серной кислот. Кроме этого, соотношение твердой и жидкой фракции изменяли от $1 / 4$ до 1/10 при продолжительности процесса от 15 до 60 мин. Полученные результаты обрабатывались стандартным методом LOESS в сочетании с трехмерной интерполяцией неполной выборки данных.

Результаты. Установлены полиномиальные зависимости, позволяющие рассчитать степень извлечения цинка из хвостов обогащения по параметрам процесса выщелачиваемого раствора, соотношению твердой и жидкой фазы в пульпе и продолжительности агитационного выщелачивания

Научная новизна. Впервые уточнен механизм трансформации поверхности, размеров и расположения зон с максимальной эффективностью выщелачивания при малых изменениях продолжительности механоактивации пульпы.

Практическая значимость. Выявленные закономерности могут быть использованы для оптимизации параметров агитационного выщелачивания путем соотношения стоимости энергозатрат на увеличение продолжительности процесса и удельных затрат на компоненты выщелачивающего раствора.

Ключевые слова: экологизация добычи руды, высокоскоростное измельчение, хвосты обогащения, выщелачивание иинка, дезинтегратор, механохимический эффект

Recommended for publication by V.S. Morkun, Doctor of Technical Sciences. The manuscript was submitted 27.03.20. 